DOI: $10.26418 /$ positron.v10i2.40104

\title{
Optimasi Ukuran dan Jumlah Pori yang Terbentuk Pada Molacularly Imprinted Polymer (MIP) Nano Karbaril $\left(\mathrm{C}_{12} \mathrm{H}_{11} \mathrm{NO}_{2}\right)$
}

\author{
Suci Apriliaa , Erry Koryantia,b, Idha Royania,b* \\ aProgram Studi Magister Fisika, Pasca Sarjana Universitas Sriwijaya \\ bJurusan FMIPA Universitas Sriwijaya, Kampus Indralaya Ogan Ilir Sumatera Selatan \\ *Email: idharoyani@unsri.ac.id
}

(Diterima 19 Maret 2020; Disetujui 6 Desember 2020; Dipublikasikan 29 Desember 2020)

\begin{abstract}
Abstrak
Telah dilakukan pembuatan molecular imprinted polymer (MIP) nano karbaril dengan metode coolingheating. Pembuatan MIP nano karbaril bertujuan untuk mendapatkan material sensor yang potensial dalam aplikasinya. Dalam penelitian ini, bahan aktif karbaril di-milling dengan variasi waktu 10 menit dan 15 menit. Pada proses polimerisasi melibatkan templat nano karbaril, methacrylic acid (MAA) sebagai monomer fungsional, ethylene glycol dimathacrylate (EDMA) sebagai crosslinker, benzoil peroksida (BPO) sebagai inisiator, dan acetonitril sebagai pelarut yang disintesis menggunakan metode cooling-heating. Dengan cara yang sama, non-imprinted polymer (NIP) juga dibuat sebagai polimer kontrol. NIP merupakan polimer yang dibuat dengan komposisi dan cara yang sama dengan MIP, namun tidak ditambahkan nano karbaril sebagai zat aktif. Pembuangan templat pada proses ekstraksi sangat berperan penting untuk menghasilkan material sensor yang baik. MIP, polimer, dan NIP yang dihasilkan di karakterisasi menggunakan Fourier transform infrared (FTIR) dan sampel terbaik dideteksi lebih lanjut dengan uji $x$-ray diffraction (X-RD), dan scanning electron microscope (SEM). Hasil FTIR menunjukkan bahwa gugus fungsi spesifik nano karbaril pada NIP tidak tampak bila dibandingkan dengan spektra MIP, dan terjadi penurunan persen transmitansi pada polimer dan peningkatan \% transmitansi pada MIP. Hal ini menjelaskan bahwa terjadi penurunan konsentrasi nano karbaril pada MIP setelah proses ektraksi. Hasil X-RD menunjukkan ukuran kristal yaitu 9,16 A. Hasil SEM menunjukkan bahwa jumlah pori tercetak dengan ukuran $\leq 100 \mathrm{~nm}$ yaitu 383 pori. Data ini mengindikasikan bahwa MIP nano karbaril potensial untuk diaplikasikan sebagai material sensor.
\end{abstract}

Kata kunci: MIP, metode cooling-heating, nano karbaril, pori

\section{Latar Belakang}

Karbaril adalah pestisida yang berfungsi untuk mengendalikan hama pada tanaman [1]. Penggunaan karbaril yang sangat intensif dan tidak terkontrol akan menyebabkan paparan karbaril yang dapat memicu reaksi alergi hipersensitivitas dan sebagai senyawa karsinogen bagi makhluk hidup [2,3]. Masalah serius muncul sebagai dampak dari residu pestisida karbaril di dalam industri makanan dan pengolahan produk pertanian selain menyebabkan masalah keamanan pangan di banyak tempat [4].

Untuk meminimalisir hal tersebut, diperlukan teknik untuk mendeteksi polutan karbaril [5]. Teknik yang bisa digunakan untuk menganalisis paparan pestisida karbaril ini diantaranya dengan menggunakan teknik molecular imprinting polymer (MIP) [6].

MIP merupakan teknik yang dikembangkan untuk menghasilkan polimer berpori melalui proses ekstraksi. Pori ini berfungsi untuk mengenal molekul target dengan ukuran, struktur serta sifat fisika kimia yang sama dengan analitnya $[5,6]$. Teknologi MIP cocok untuk analisis kimia organik seperti obat-obatan, pestisida, steroid, dan racun [7].

Sebagai material sensor, MIP harus memiliki karakteristik yang baik, yaitu pori tercipta mampu mengenali target dengan kesamaan struktural baik bentuk, ukuran, struktur molekul, atau kelompok fungsional template [8]. MIP juga harus memiliki selektivitas dan afinitasnya yang tinggi untuk molekul template-nya, stabilitas termal dan kimia yang baik, menginduksi ikatan kimia yang kuat, dan menunjukkan stabilitas terhadap panas dan tekanan [9].

Metode yang umumnya digunakan dalam sistesis MIP yaitu dengan mengalirkan nitrogen kemudian diberi sinar ultraviolet $[8,10]$. Namun, kelemahan teknik tersebut adalah membutuhkan biaya yang cukup mahal dan waktu yang lama [11]. 
Metode cooling-heating (pendinginan-pemanasan) diperkenalkan untuk mempermudah dalam preparasi MIP. Dibandingkan dengan metode pengaliran nitrogen pada larutan pra-polimer yang membutuhkan waktu lebih lama [12], proses sintesis dengan metode cooling-heating ini lebih efisien.

Program penilaian kualitas air nasional Amerika Serikat mengkategorikan karbaril sebagai pestisida kedua yang paling sering ditemukan di dalam air dengan ukuran yang sangat kecil, dengan demikian akan sulit terdeteksi jika membran cetakan yang dihasilkan tidak berukuran nano [4]. Oleh karena itu, untuk meminimalisir hal tersebut bahan aktif karbaril yang digunakan di-milling dengan alat high energy milling (HEM) untuk mendapatkan serbuk dengan ukuran partikel yang kecil. Dengan menambahkan waktu milling, maka ukuran partikel yang dihasilkan semakin kecil [13].

Sifat kimia dan fisika dari suatu material akan berubah secara drastis ketika direduksi ukurannya menjadi nano. Material berukuran nano memiliki sifat mekanik yang lebih unggul dari material ukuran besar (bulk). Demikian juga halnya dengan reaktivitas material tersebut yang berubah secara drastis saat berukuran nano. Makin kecil ukuran partikel maka makin reaktif partikel tersebut terhadap rekasi kimia [14].

Dalam penelitian ini, dilaporkan proses pembuatan MIP nano karbaril, polimer karbaril, dan non-imprinted polymer (NIP). NIP berfungsi sebagai polimer kontrol yang dibuat dengan cara yang sama dengan pembuatan polimer, namun tanpa menambahkan bahan aktif karbaril. Kemudian, diselidiki pengaruh waktu milling terhadap ukuran dan jumlah pori pada MIP nano partikel karbaril dengan memvariasikan waktu milling yaitu 10 menit dan 15 menit. Pemilihan waktu milling tersebut merupakan optimasi waktu milling. Jika waktu milling kurang dari 10 menit maka bahan aktif karbaril yang dihasilkan memiliki sebaran ukuran yang cukup lebar, sedangkan jika waktu milling lebih dari 15 menit maka bahan aktif nano kabaril akan mengalami penggumpalan (aglomerasi).

MIP nano karbaril yang dihasilkan telah diuji karakteristiknya dan hasil memberikan informasi bahwa dengan mereduksi ukuran partikel dapat menghasilkan partikel dengan ukuran pori yang kecil dan distribusi ukuran yang lebih seragam. Karakterisasi telah dilakukan menggunakan
Fourier transform infrared (FTIR) Nicolet is10 FTIR Spectrometer, $x$-ray diffraction (X-RD) Rigaku Miniflex 600, dan scanning electron microscopy (SEM) tipe TESCAN VEGA III.

\section{Metodologi}

Penelitian ini dilakukan dalam tiga tahapan berikut.

\section{A. Tahap Milling}

Bahan aktif karbaril 200 mg masing-masing dimilling $100 \mathrm{mg}(0,1 \mathrm{gr})$, menggunakan dua variasi waktu milling, 10 menit dan 15 menit. Ball to powder ratio (BPR)/rasio bola dan serbuk yang digunakan adalah sama yaitu 80:1.

\section{B. Tahap Polimerisasi}

Pertama, serbuk nano karbaril sejumlah 0,028 g dimasukkan ke dalam pelarut $3,14 \mathrm{ml}$ acetonitril dan diaduk menggunakan magnetic stirrer. Kemudian, 0,44 ml methacrylic acid (MAA), 1,9 mL ethylene glycol dimathacrylate (EDMA), 0,03 g benzoil peroksida (BPO) juga dimasukkan kedalam larutan tadi sedikit demi sedikit sambil terus diaduk selama 15 menit hingga semua bahan terlarut sempurna. Kedua, larutan dimasukkan ke dalam vial tertutup dan didinginkan pada suhu -5 ${ }^{\circ} \mathrm{C}$ selama 1 jam. Selanjutnya, larutan pra polimer di dalam vial dipanaskan dengan menaikkan suhunya secara bertahap, yaitu $75^{\circ} \mathrm{C}$ selama 3 jam, $80{ }^{\circ} \mathrm{C}$ selama 2 jam, dan $85^{\circ} \mathrm{C}$ selama 1 jam. Kemudian, polimer padat yang dihasilkan digerus sampai halus. Selanjutnya, karakterisasi dilakukan menggunakan FTIR untuk membandingkan \% transmitansi dari NIP dan MIP nano karbaril yang milling selama 10 dan 15 menit.

\section{C. Tahap Ekstraksi}

Proses pencucian (ekstraksi) dilakukan sebanyak empat tahap. Pertama, pencucian dengan pelarut acetonitril selama 16 jam, dilakukan sebanyak 3 kali pengulangan. Kedua, pencucian dengn pelarut metanol dan asam asetat (1:20) selama 1 jam, dilakukan 3 kali pengulangan. Ketiga, pencucian dengan pelarut metanol selama 1 jam, dilakukan 3 kali pengulangan. Keempat, pencucian dengan pelarut methanol dan aquabidest (1:20) selama 1 jam, dilakukan 3 kali pengulangan.

Larutan dibuang dan serbuk polimer dikeringkan selama \pm 24 jam. Selanjutnya, serbuk polimer dikarakterisasi menggunakan FTIR. Dari kedua sampel tersebut, hasil yang terbaik dilanjutkan dengan uji karakterisasi X-RD, dan SEM. 


\section{Hasil dan Pembahasan}

Sintesis MIP yang melibatkan monomer fungsional MAA dengan molekul target yang bertindak sebagai template, yaitu karbaril berinteraksi melalui ikatan kovalen dan non kovalen, dibantu cross-linker EDMA untuk membentuk struktur polimer, dan inisiator BPO untuk mempercepat rekasi polimerisasi. Selanjutnya, pembentukan pori dilakukan dengan cara penghapusan template karbaril (ekstraksi) dari polimer. Pori tersebut melengkapi molekul target secara spesifik dalam hal bentuk, ukuran, struktur, dan kelompok-kelompok fungsional yang sama [11,15]. Selanjutnya, keberhasilan dalam pembuatan MIP dapat di uji dengan menggunakan FTIR untuk mengetahui gugus fungsi dan persentase transmitasi dari sampel, XRD untuk melihat ukuran kristal dari polimer, dan SEM untuk mengetahui data permukaan sampel dan analisis jumlah serta ukuran pori yang terbentuk pada MIP nano karbaril.

\section{A Fourier Transform Infrared}

Spektrum FTIR yang menunjukkan unsurunsur yang terkandung di dalam MIP nano karbaril 10 menit, dan MIP nano karbaril 15 menit, polimer nano karbaril 10 menit, polimer nano karbaril 15 menit, dan NIP yang disajikan dalam Gambar 1(a) sampai Gambar 1(e). Pada gambar ini, dapat dilihat bahwa spektrum FTIR yang dihasilkan antara MIP nano karbaril, polimer nano karbaril, dan NIP menunjukkan adanya perbedaan persen transmittansi. Hal ini menjelaskan adanya perbedaan jum- lah konsentrasi yang terkandung dalam masingmasing sampel.

Gambar 1 (a) dan (b) memberikan informasi bahwa pada polimer terdapat gugus fungsi $\mathrm{O}-\mathrm{H}$ (ulur) pada bilangan gelombang 2500-3300 $\mathrm{cm}^{-1}$ yang mengkonfirmasi keberadaan gugus asam karboksilat MAA. Kehadiran dua puncak yang signifikan pada gugus fungsi $\mathrm{C}=0$ (ulur) di bilangan gelombang 1690-1760 $\mathrm{cm}^{-1}$ dan gugus fungsi C-O (ulur) pada bilangan gelombang 1000-1300 cm-1 menunjukkan keberadaan dari EDMA. Gugus fungsi C-O (ulur) pada $1046 \mathrm{~cm}^{-1}$ berasal dari rantai monomer [16]. Pada bilangan gelombang 1180$1359 \mathrm{~cm}^{-1}$ terdapat gugus fungsi C-N (amina, ulur) [17] dan pada bilangan gelombang 650-750 $\mathrm{cm}^{-1}$ terdapat gugus fungsi N-H (amina sekunder), yang merupakan kelompok fungsional amina sebagai ciri khas gugus fungsi karbaril $[17,18]$. Gugus asam karboksilat pada MAA dengan molekul target yang bertindak sebagai template yaitu nano karbaril berinteraksi melalui interaksi kovalen dan non kovalen [19]. Dibuktikan pada Tabel 1, bahwa gugus fungsi $\mathrm{C}-\mathrm{N}$ dan $\mathrm{C}=\mathrm{O}$ mengalami pergeseran bilangan gelombang pada polimer di waktu milling 10 menit dan 15 menit [18]. Persen transmitansi pada polimer 10 menit lebih besar dari polimer 15 menit. Hal ini menjelaskan konsentrasi zat yang terkandung pada polimer 10 menit lebih sedikit jika dibandingkan dengan polimer 15 menit.

Gambar 1 (c) dan (d) memberikan informasi bahwa semua puncak transmitansi spektrum FTIR MIP nano karbaril menjadi berkurang setelah proses pembuangan template. Hal ini dapat dilihat
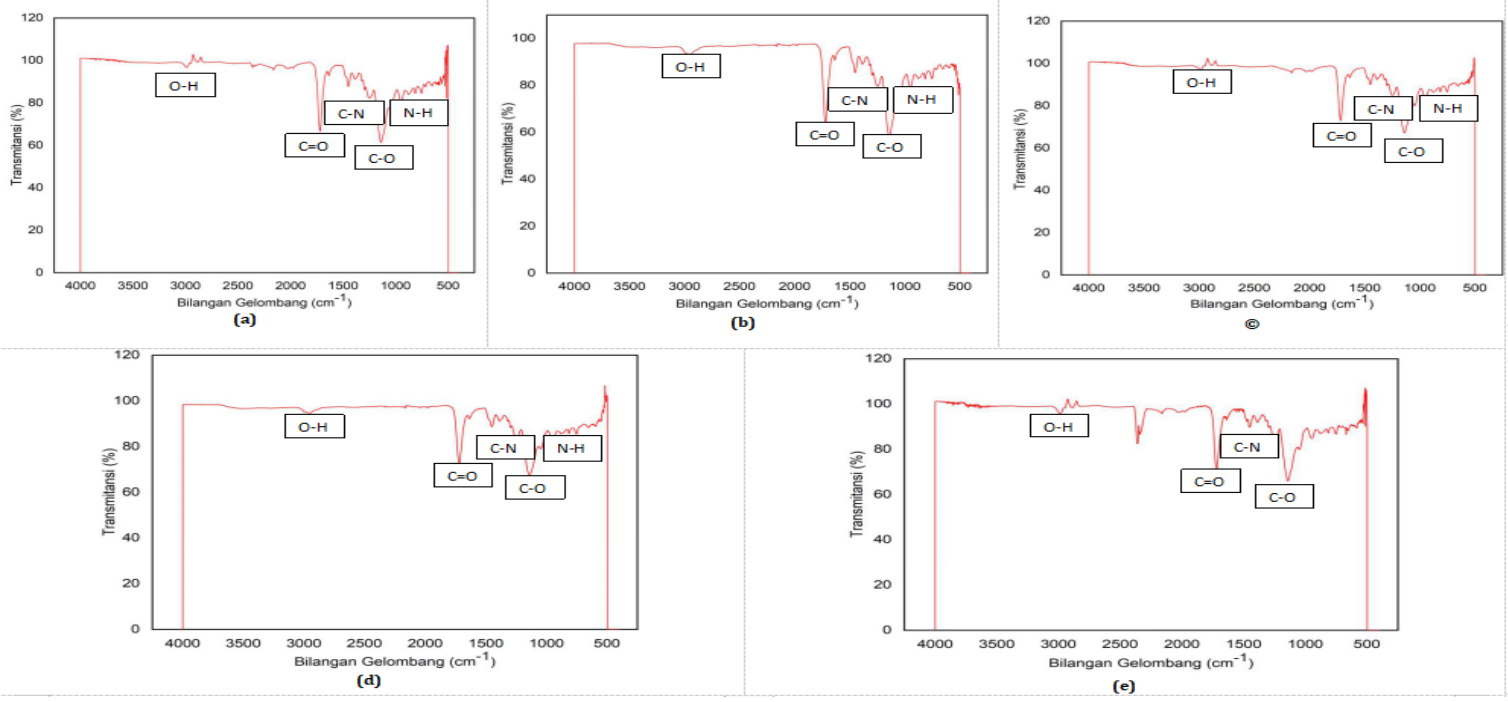

Gambar 1. (a) Polimer nano karbaril 10 menit, (b) Polimer nano karbaril 15 menit, (c) MIP nano karbaril 10 menit, (d) MIP nano karbaril 15 menit, (e) NIP. 
Tabel 1. Persen transmitansi dan gugus fungsi dari kelompok fungsional NIP, Polimer dan MIP nano karbaril hasil milling 10 menit dan 15 menit.

\begin{tabular}{|c|c|c|c|c|c|c|c|c|c|c|}
\hline \multirow{3}{*}{$\begin{array}{l}\text { Gugus } \\
\text { Fungsi }\end{array}$} & \multirow{2}{*}{\multicolumn{2}{|c|}{ NIP }} & \multicolumn{4}{|c|}{ Polimer } & \multicolumn{4}{|c|}{ MIP } \\
\hline & & & \multicolumn{2}{|c|}{10 menit } & \multicolumn{2}{|c|}{15 menit } & \multicolumn{2}{|c|}{10 menit } & \multicolumn{2}{|c|}{15 menit } \\
\hline & $\begin{array}{c}\mathbf{k} \\
\left(\mathrm{cm}^{-1}\right)\end{array}$ & $\begin{array}{c}T \\
(\%)\end{array}$ & $\begin{array}{c}\mathbf{k} \\
\left(\mathrm{cm}^{-1}\right)\end{array}$ & $\begin{array}{c}T \\
(\%)\end{array}$ & $\begin{array}{c}\mathbf{k} \\
\left(\mathrm{cm}^{-1}\right)\end{array}$ & $\begin{array}{c}T \\
(\%)\end{array}$ & $\begin{array}{c}\mathbf{k} \\
\left(\mathrm{cm}^{-1}\right)\end{array}$ & $\begin{array}{c}\mathrm{T} \\
(\%)\end{array}$ & $\begin{array}{c}\mathbf{k} \\
\left(\mathrm{cm}^{-1}\right)\end{array}$ & $\begin{array}{c}T \\
(\%)\end{array}$ \\
\hline $\mathrm{O}-\mathrm{H}$ & 2885 & 98 & 2988 & 96 & 2989 & 94 & 2989 & 97 & 2953 & 95 \\
\hline$C=0$ & 1716 & 71 & 1717 & 67 & 1720 & 64 & 1717 & 73 & 1717 & 73 \\
\hline C-N & 1249 & 84 & 1248 & 82 & 1247 & 80 & 1247 & 85 & 1247 & 84 \\
\hline C- 0 & - & - & 1046 & 76 & 1046 & 75 & - & - & - & - \\
\hline $\mathrm{N}-\mathrm{H}$ & - & - & 652 & 88 & 654 & 87 & 653 & 89 & 653 & 89 \\
\hline
\end{tabular}

$\mathrm{k}$ : Bilangan gelombang $\left(\mathrm{cm}^{-1}\right)$

T: Transmitansi (\%)

dari selisih persen transmitansi antara polimer nano karbaril dan MIP nano karbaril. Selisih terbesar terdapat pada MIP nano karbaril 15 menit yang menunjukkan konsentrasi berkurang cukup signifikan. Semakin kecil ukuran partikel maka semakin reaktif partikel tersebut terhadap reaksi kimia [14]. Dengan demikian, dapat dikatakan bahwa semakin lama waktu milling, semakin kecil ukuran partikel [13] yang dapat mempermudah pelepasan karbaril pada saat proses ekstraksi [19].

Gambar 1 (e) menunjukkan gugus fungsi N-H (amina sekunder) yang mencirikan gugus fungsi amina sebagai ciri khas dari karbaril tidak muncul di NIP, karena tidak ada tambahan karbaril yang diberikan selama proses sintesis NIP. Oleh karena itu, NIP yang disintesis termasuk ke dalam gugus asam karboksilat [16]. Berdasarkan analisis hasil FTIR dapat dilaporkan bahwa MIP nano karbaril 15 menit dipilih sebagai sampel terbaik dalam proses ekstraksi. Kemudian, dapat dilakukan karakterisasi lebih lanjut dengan uji karakterisasi X-RD dan SEM. Persen transmitansi dan bilangan gelombang dari masing-masing sampel ditabulasikan dalam Tabel 1.

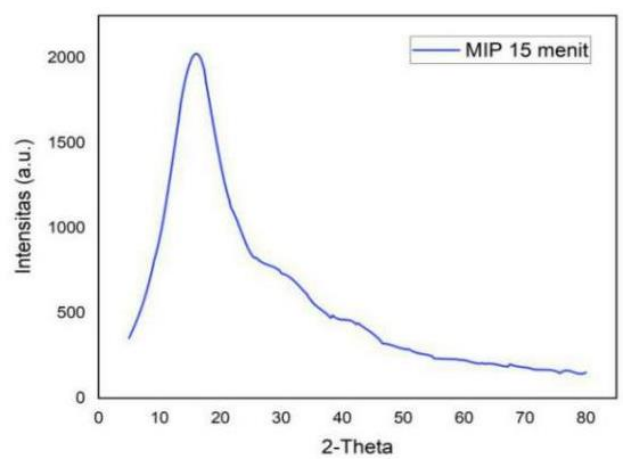

Gambar 2. Hasil X-RD MIP nano karbaril 15 menit.

\section{B. X-RAY Diffraction}

Analisis ukuran kristal dalam MIP nano karbaril telah dilakukan. Hasil grafik X-RD MIP nano karbaril 15 menit disajikan dalam Gambar 2.

Gambar 2 menunjukkan pola X-RD dari MIP nano karbaril 15 menit. Ukuran kristal ditentukan dengan persamaan Scherrer [15]

$$
D=\frac{k \lambda}{B \cos \theta},
$$

dengan $D$ adalah ukuran kristal, $\lambda$ adalah panjang gelombang sinar-X, B adalah full width at half maximum (FWHM) yang dihitung dalam radian, $\theta$ merupakan sudut difraksi dan $k$ adalah konstanta material yang nilainya 0,9 [15]. Ukuran kristal yang dihasilkan disajikan pada Tabel 2.

Nilai intensitas pada Tabel 2 yaitu $16,25^{\circ}$ menunjukkan di daerah tersebut terdapat banyak atom yang mendifraksikan sinar-X. Untuk memperkuat uji karakterisasi X-RD, dilakukan uji morfologi dari MIP nano karbaril 15 menit, guna mengetahui berapa banyak jumlah pori dan ukuran pori yang tercetak.

Tabel 2. Hasil X-RD MIP nano karbaril 15 menit.

\begin{tabular}{|c|l|c|}
\hline No & \multicolumn{2}{|c|}{ MIP Nano Karbaril 15 menit } \\
\hline 1 & $2 \theta(\mathrm{deg})$ & 16,25 \\
\hline 2 & $\mathrm{~d}(\AA)$ & 5,45 \\
\hline 3 & FWHM $(\mathrm{deg})$ & 8.76 \\
\hline 4 & $\mathrm{D}(\AA)$ & 9,16 \\
\hline
\end{tabular}

\section{C. Scanning Electron Microscopy}

Pada penelitian ini, analisis SEM digunakan untuk mengetahui struktur permukaan berupa jumlah pori dan ukuran pori yang terbentuk. Morfologi MIP nano karbaril disajikan dari hasil SEM pada Gambar 3. 


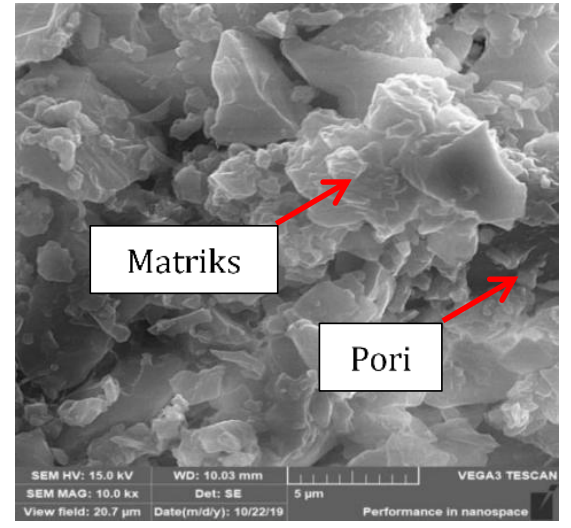

Gambar 3. Hasil SEM MIP nano karbaril 15 menit.

Pengolahan hasil morfologi MIP nano karbaril 15 menit dari SEM dilakukan dengan software porediz. Teknik pencitraan ini memberikan informasi berupa pembagian warna dengan bilangan biner. Dari penyeleksian ini, dapat diestimasikan sifat fisis sampel, yakni ukuran dan jumlah pori [20]. Hasil pengolahan gambar menggunakan software porediz untuk pengolahan gambar citra biner di sajikan dalam Gambar 4 .

Gambar 4 menunjukkan hasil citra biner dengan tahap segmentasi pembagian gambar menjadi beberapa objek berdasarkan level intensitas dan pendeteksian tepi objek. Level intensitas ini dikenali dari perbedaan warna yang kontras antara padatan dengan pori. Objek matriks diberi warna hitam sebaliknya objek pori diberi warna putih [20]. Data ini diolah lebih lanjut untuk mendapatkan informasi yang dibutuhkan.

Hasil analisis yang diperoleh dari software porediz dapat dilihat pada histogram distribusi ukuran pori terhadap jumlah pori yang disajikan pada Gambar 4.

Gambar 5 menunjukkan bahwa jumlah pori yang dihasilkan dengan ukuran di bawah $\leq 100 \mathrm{~nm}$

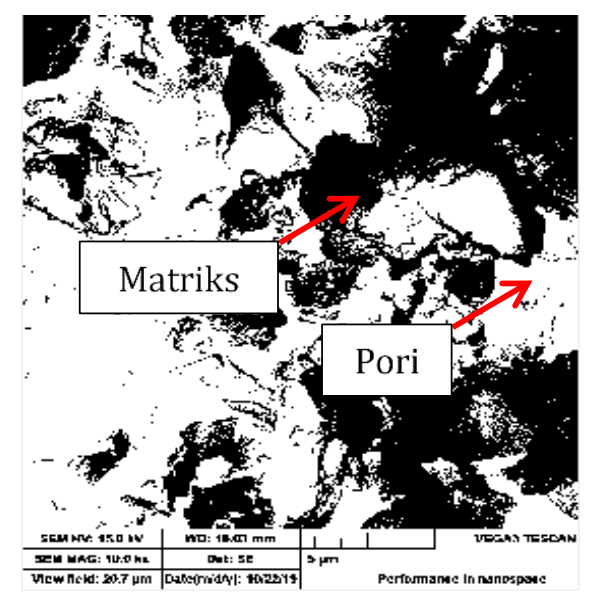

Gambar 4. Citra biner MIP nano karbaril 15 menit.

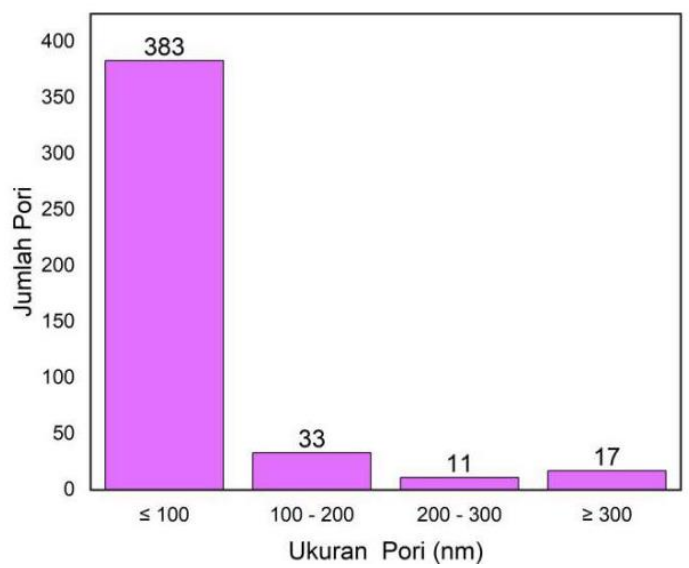

Gambar 5. Histogram distribusi ukuran pori terhadap jumlah pori yang terbentuk pada MIP nano karbaril 15 menit.

sebanyak 383 dengan rentang ukuran pori dari 32$100 \mathrm{~nm}$, ukuran 100-200 nm sebanyak 33 pori, ukuran 200-300 nm sebanyak 11 pori, dan ukuran $\geq 300 \mathrm{~nm}$ sebanyak 17 pori. Dari hasil yang diperoleh, dapat dilihat bahwa reduksi ukuran partikel karbaril ke dalam skala nano dapat mempermudah proses ekstraksi [20]. Hal ini dikarenakan volume partikel karbaril setelah direduksi semakin kecil, mengakibatkan ikatan antar atom-atom penyusun partikel semakin lemah sehingga mudah terlepasnya partikel karbaril dari ikatan rantai polimer dan membentuk cetakan yang berfungsi untuk mengenali analit $[7,14]$. Dengan semakin banyak jumlah pori yang dihasilkan dalam skala nano, diharapkan semakin selektif MIP nano karbaril dalam mendeteksi residu senyawa karbaril yang berukuran nano di lingkungan.

\section{Kesimpulan}

Dari penelitian yang telah dilakukan dapat disimpulkan bahwa hasil FTIR menunjukkan terjadi penurunan konsentrasi nano karbaril paling besar di MIP nano karbaril 15 menit, yang diperlihatkan oleh gugus fungsi $\mathrm{N}-\mathrm{H}$ sebagai penciri karbaril. Hal ini dilihat dari selisih persen transmitansi antara polimer nano karbaril dan MIP nano karbaril. Selisih terbesar terdapat di MIP nano karbaril 15 menit. Hasil X-RD menunjukkan dengan mereduksi ukuran karbaril menggunakan HEM, diperoleh ukuran kristal sebesar 9,16 Å. Berdasarkan hasil pengolahan citra SEM diperoleh jumlah pori berukuran $\leq 100$ nanometer yang terbentuk sebanyak $383 \mathrm{~nm}$. Hal ini mengindikasikan bahwa material MIP nano karbaril ini berpotensi untuk diaplikasikan sebagai material sensor. 


\section{Ucapan Terima Kasih}

Terima kasih disampaikan kepada Lembaga Penelitian dan Pengabdian Masyarakat Universitas Sriwjaya atas dukungan dana penelitian melalui Hibah Kompetitif Universitas Sriwijaya dengan no kontrak 0015 / UN9 / SK.LP2M.PT / 2019.

\section{Daftar Pustaka}

[1] Roni. S, Degradasi Senyawa Carbaryl Dalam Pestisida Sevin 85 S Secara Sonolisis, Ozonolisis Dan Sonozolisis, Sci. J. Farm. dan Kesehat, 8 (2),2014.

[2] S. F. Kimia, Karbaril, Sifat Fis. dan Kim. karbaril, 1(2), p 3, 2010.

[3] A. A. Bazrafshan, M. Ghaedi, Z. Rafiee, S. Hajati, and A. Ostovan, Nano-sized molecularly imprinted polymer for selective ultrasoundassisted microextraction of pesticide Carbaryl from water samples: Spectrophotometric determination, J. Colloid Interface Sci., 498, pp. 313-322, 2017.

[4] Juyhok, S. Pang, C. Dong, H. Jang, P. U, J. Ri, K. Yun, C. Adsorption of 1-Naphthyl Methyl Carbamate in Water By Utilizing a Surface Molecularly Imprinted Polymer. Pyongyang: University of Science. 2018.

[5] Z. Zhang, T. Si, J. Liu, and G. Zhou, In-situ grown silver nanoparticles on nonwoven fabrics based on mussel-inspired polydopamine for highly sensitive SERS carbaryl pesticides detection, Nanomaterials, 9, (3), 2019.

[6] I. Royani and M. Abdullah, Pembuatan Polimer MIP (Molecularly Imprinted Polymer) Atrazin Untuk Diaplikasikan Sebagai Material Sensor, pp. 77-79, 2012.

[7] L. D. de León-Martínez et al., Synthesis and Evaluation of a Molecularly Imprinted Polymer for the Determination of Metronidazole in Water Samples, Bull. Environ. Contam. Toxicol., 100 (3), pp. 395-401, 2018.

[8] W. Yao, Y. Fang, G. Li, Z. Gao, and Y. Cheng, composite - super paramagnetic behavior and variable range hopping 1D conduction mechanism - synthesis and characterization, Polym. Adv. Technol.,19,pp. 812-816, 2008.

[9] C. Zhang, H. Cui, Y. Han, F. Yu, and X. Shi, Development of a biomimetic enzyme-linked immunosorbent assay based on molecularly imprinted polymers on paper for the detection of carbaryl, Food Chem.,240, pp. 893-897, 2018.
[10] Orowitz, TE. Sombo, PP. Rahayu, D. Hasanah, A. 2020. Microsphere Polymers in Molecular Imprinting: Current and Future Perspectives. Academic Editors: Alireza Ghiasvand, Joselito P. Quirino and Yunlei Xianyu Received: 27 June 2020; Accepted: 14 July 2020; Published: 17 July 2020 .

[11] I. Royani, Assaidah, Widayani, M. Abdullah, and Khairurrijal, The effect of atrazine concentration on galvanic cell potential based on molecularly imprinted polymers (MIPS) and aluminium as contact electrode, J. Phys. Conf. Ser., 1282 (1), 2019.

[12] I. Royani, Widayani, M. Abdullah, and Khairurrijal, An atrazine molecularly imprinted polymer synthesized using a cooling-heating method with repeated washing: Its physico-chemical characteristics and enhanced cavities, Int. J. Electrochem. Sci., 9 (10), pp. 5651-5662, 2014.

[13] Sarimai, Ratnawulan, Ramli, and A. Fauzi, Pengaruh Waktu Milling Terhadap Dan Ukuran Butir Forsterite, 8, pp. 65-72, 2016.

[14] M. Abdullah, Pengantar Nanomaterial, MIPA Fisika ITB pp. 26-63, 2008.

[15] Cullity and Stock, Mechanism of calciumindependent phosphorylation of sarcoplasmic reticulum ATPase by orthophosphate. Evidence of magnesium-phosphoprotein formation, 108(2), 2014.

[16] Yanti, T. Nurhayati, I. Royani, Widayani, and Khairurrijal, Synthesis and characterization of MAA-based molecularly-imprinted polymer (MIP) with D-glucose template, J. Phys. Conf. Ser.,73(1),2016.

[17] D. Skoog, J. Holler, and S. Crouch, Parallel GF(2n) multipliers, 2018.

[18] S. Chen et al., Preparation and characterization of magnetic molecular imprinted polymers with ionic liquid for the extraction of carbaryl in food, 2019.

[19] R. Gui, Nanoscale Advances Preparation and applications of electrochemical chemosensors based on carbon-nanomaterial- modi fi ed molecularly imprinted polymers, pp. 33253363, 2019.

[20] M. Rosi, U. Fauzi, M. Abdullah, and K. Khairurrijal, Pengolahan Citra SEM dengan Matlab untuk Analisis Pori pada Material Nanopori Pengolahan Citra SEM dengan Matlab untuk Analisis Pori pada Material Nanopori, pp. 1-4, 2009. 